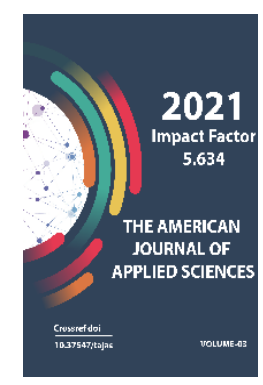

Journal Website: http:/ theamericanjournals.c om/index,php/tajabe

Copyright: Original content from this work may be used under the terms of the creative commons attributes 4.0 licence.

\section{Construction Of Econometric Models Of Development Of Services For The Population In The Region And Forecasting Them}

\author{
Anvar Norimovich Rakhimov \\ Associate Professor, Karshi Engineering-Economical Institute, Uzbekistan \\ Golibjon Kholmuminovich Makhmatkulov \\ Assistant, Karshi Engineering-Economical Institute, Uzbekistan \\ Abdihakim Muhammadiyevich Rakhimov \\ Assistant, Karshi Engineering-Economical Institute, Uzbekistan
}

\title{
ABSTRACT
}

Analyzing development processes of each sector of the service sector, the sequence of choosing and modeling the main factors which influence their development are represented through simulation schemes in this article. Multifactorial empirical models were built on the example of the service sector which is provided to the population of Kashkadarya region, forecasts were given through them and suggestions and recommendations were given on the basis of obtained results.

\section{KEYWORDS}

Service sector, complex modeling, econometric modeling, differential equations, static and dynamic parameters, structural analysis, synthesis, optimization, multifactorial empirical models, regression equation, correlation coefficient, Darbin-Watson criterion, Fisher and student criteria.

\section{INTRODUCTION}

The development of digital (information) technologies is currently affecting almost all areas of economic activity in current level. Studying forecast of the quality of services to the population of the region on the basis of empirical models and forecasting results are emphasized in this article.

The aim of the research is considered to develop an empirical model of forecasting and 
increase the efficiency of the use of "digital information systems in the field of services to the population in the region".

The research was conducted using analysis and generalization tools to identify and classify problem area boundaries. A systematic approach and digital information technology were used in shaping the empirical model of forecasting and describing its individual elements.

Nowadays the prevalence of digital technologies in Uzbekistan, "reducing the difference in the level of social-economical development of regions, first of all, accelerating the development of comparative districts and cities by improving the quality of services to the population through widening scales of modernization and diversification of the economy of regions" are set out in given Annex 1 of the Decree of the President of the Republic of Uzbekistan No. 4947 of February 7, 2017 "On Action Strategy for the five priorities for further development of the Republic of Uzbekistan in 2017-2021 years" .

"The important tasks in the future not only for the basic sectors of the economy, but, first of all, for the integrated development of the regions and ensuring the vital interests of all citizens and increasing their incomes" should exist in order to further deepen the reforms in carrying out these tasks $[1 ; 2]$.

Over the past 30 years, great attention has been paid on the empirical modeling of the impact of information technology on the activities of the service sector and the optimal management of the economic system of the region in the scientific work of scientists of foreign and our republic. In this field, some aspects of the optimal regulation of the economic system of the regions have been studied in the research of M.Keyns from foreign scientists, V.M.Granberg from Russian scientists [5; 14] together with this, in the research of scientists of our country. In particular, the theoretical and methodological aspects of complex and balanced development of the regions are reviewed in the works of B.Ruzmetov [15]. Despite of longterm researches, exact forecasting of development of economic system remains a actual issue.

\section{METHODS}

A lot of discussion about building an empirical model of forecasting services to the population of the region using digital technologies were held. It has been pointed out that the application of complex numerical econometric models in forecasting economic growth is considered one of the most perspective methods in the research of R.Arens, N.R.Gudman, and R.A.Wooding. Interest in regression complex econometric models with statistical observation and functions with complex numerical variables appeared in the 50-60s of the XX century. The attention has also focused on this direction in the researches of Tavares G.N., Tavares L.M.. Only in 2004, the Russian economist S.G.Svetunkov first created the theory of formation econometric models with complex number. This was based for the formation of complex numerical economy [16;17; 18; 21]. As noted in the researches of Afanaseva A.A., Ponomareva O.S. and Kleiner G.B., "the description of the impact of such production functions, the impact of production resources on production results helps to solve many practical problems" [19; 20]. In the scientific researches of T.V.Merkulov and F.I.Prixodko, "The advantage of complex numerical econometric modeling is that the opportunity for solving complex problems with real variable functions with using them". The important factor in the region system is considered the theory of optimal regulation. Its distinctive features are analyzed and appropriate scientific conclusions are given about the need for consistent application of the principle of optimality in solving all complex problems of regulation and 
management of economic processes in the region [22].

According to the famous american researcher P. Strassman, investments in information technologies are most closely associated with indicators such as the administrative and management costs of service enterprises. The information tools and technologies can reduce the internal management costs of the field [6].

P.David emphasizes in his works that information technologies is a "generalpurpose technology" [7]. A similar view was emphasized by professor of Harvard Business School G.S. Loveman [8]. Information technologies creates potential for the development of other digital technologies, but technologies which do not exist without digital technologies, they do not benefit quickly by themselves. The information technology provides a platform for improving organizational processes of existing service sector and the introduction of completely new tools.

In the works of modern authors, a number of fields of evaluation of the introduction of information technologies in the service sector are highlighted [9; 11; 12; 13], it can be divided into the following classifications:

Using classical methodology in the evaluation of investment projects and programs on the basis of international standards;

Using economical methods in calculating the addition of the factor to the overall result, saving money, calculation of the system of financial indicators, assessment of the level and dynamics of indicators by sectors (when using the information system);

Applying expert assessment methods (usefulness, prospects, opportunity of use,, ease of use of information resources, etc.);
Using information diagnostic methods (networkmetry, webometry).

A similar operation was carried out by E.Brinolfsson and L.Hitch who studied the activities of 527 major American firms [16]. In this approach, the authors emphasized that additional assets (assets which change under the influence of information technologies: experience and skills of workers, communication tools and technologies, quality of making decision, changes in business processes, and etc.) plays an important role. Over passing time, the results of implementation of digital technologies will be gradually shown, in general terms.

The complexity of systems of the service sector to the population (systems on the basis of using information technologies) requires taking into account the specific characteristics of digital technologies. It is responsible for the intellectual reprocessing of information about changes of the state (efficiency) of complex objects and ensures the selection of management decisions [3; 4].

\section{RESULTS AND DISCUSSION}

There are two approaches to create digital economy: planned and market [2; 15]. The development of the service sector for developing countries is considered one of the most effective ways to improve the living standards of the population. The main task includes not only to increase the share of service sector in GDP, but also to expand its structure, increase employment degree, develop modern forms and technologies of services which fully supply the needs of the population.

The main part of the employed population in developed countries, in particular, "80 percent in the United States and more than 70 percent in Japan, corresponds to the contribution of the service sector". On the other hand, a number of U.S. companies, 
possess at least for more than 50 percent of revenue in production through selling services related to producing $[23 ; 24]$.

Empirical methods do not negate simple, traditional methods, but help to further develop them and to analyze objectively variable outcome indicators through other indicators.

The real object is presented in the form of two systems: control and controllable (control object) in econometric modeling of the development of service sectors, in the description of management processes.
The general structure of control systems in econometric modeling of the multidisciplinary service sector is shown in Figure 1. It includes endogenous variables: $\vec{x}(t)$ - vector of input influences (task); $\vec{v}(t)$ - vector of external environment influences; $\overrightarrow{h^{\prime}}(t)$ - vector of errors signal; $\vec{h}^{\prime \prime}(t)$ - vector of control influences; exogenous variables: $\vec{z}(t)$ - vector of S system state; $\vec{y}(t)$ - vector of the output variables, it is usually $\vec{y}(t)=\vec{z}(t)$.

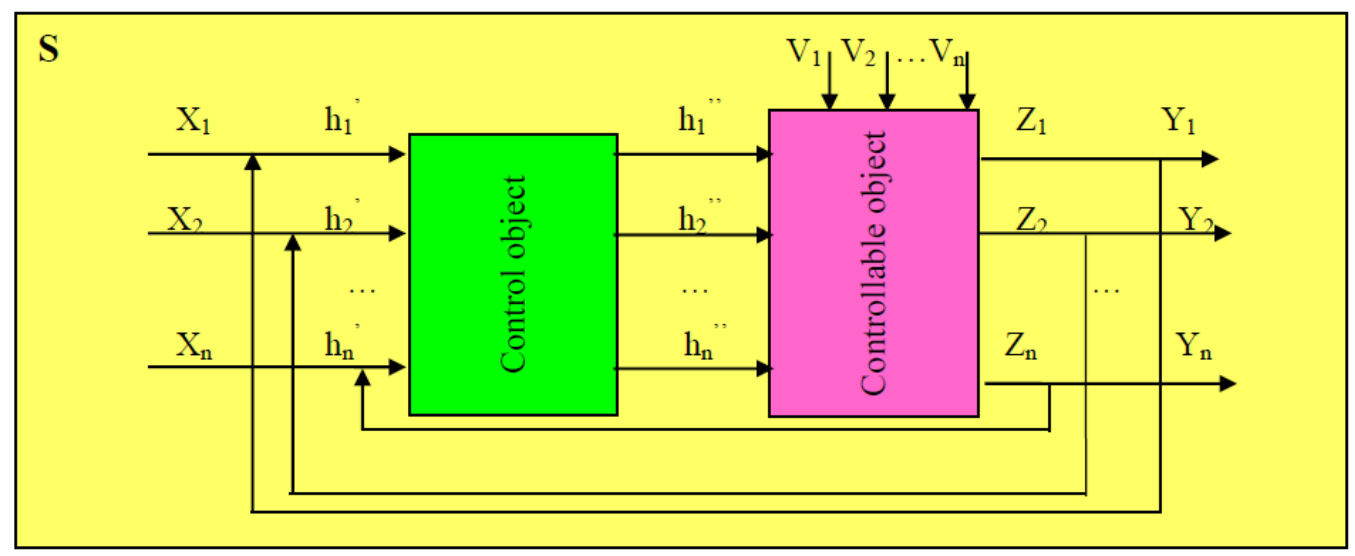

Figure 1. The structure of the management system in the econometric modeling of the development of service sectors

In the present case, the control system of econometric modeling is considered a set of software and hardware which provides a specific target control system. It is possible to make a decision on the $y(t)$ state coordinate for a one-dimensional system depending on how far the control object reaches the target. The difference between the task value $y_{\text {zad }}(t)$ and the real value $y(t)$ of the control quantity change law is considered $h^{\prime}(t)=y_{z a d}(t)-y(t)$ control error. If the given control quantity change law coincides with the input influences (task) change law, namely, if it is $x(t)=y_{\text {zad }}(t)$, then it will be $h^{\prime}(t)=x(t)-y(t)$.
A system with a control error $h^{\prime}(t)=0$ for all time moments is called an ideal system. In practice,

it is not possible to develop ideal systems. Therefore, the error in automatic control should be reduced on the basis of the principle of reserve connection (giving as information about the deviation between them with using the output variable $y(t)$ and its task values ).

In econometric modeling, the task of control systems is considered change of the variable $y(t)$ in given accuracy (with permitted error) in accordance with the law. When projecting and 
operating automatic control systems, it is necessary to select the parameters which can ensure the required control accuracy of the $S$ system, as well as its stability during the transition process.

If the system becomes stable, then its behavior by time, the maximum deviation of the adjustment variable $y(t)$ in the transient process, the transient process time, and others are of practical interest. The properties of different classes of automatic control systems can be concluded by the types of differential equations which most closely describe the processes in the system. The order of the differential equations and the value of the coefficients completely determine the static and dynamic parameters of the system.

Using Figure 1. gives opportunity to accept analytical or imitation approaches which are developed in the form of appropriate language for modeling continuous systems or using analog and hybrid computational techniques in forming the process of continuous-determined $\mathbf{S}$ systems activity and evaluating their basic characteristics.

The importance of econometric modeling of public service sectors is reflected in the followings:

The material, labor and monetary resources are rationally used;

It serves as a leading tool in the analysis of economic and natural processes;

It will be possible to make some adjustments during the forecasting of the development of public service sectors;

It gives opportunity not only in-depth analyzing service sectors, but also discovering their unexplored new laws. They can also be used to predict the future development of service sectors;
It facilitates mental work along with the automation of computational work, creates the opportunity to organize and manage the work of personnel of service sector on the scientific basis.

In our opinion, there are the following actual issues which are waiting for their solution, in the development of the service sector: identifying classification of the types of services which are provided to the population, evaluating the nature of the service sector, developing a system of indicators of service sectors in current situation, improving the process of econometric modeling of development of public service sectors and forecasting it through them.

Human creates and serves the object of service to himself. Because of this, it is possible to introduce the belief that services are for the human and performing the service is also a human. This means that both the producer of the services and its consumer are also human. This can be expressed as follows:

It is known that as a result of the service, the GDP of country will increase. This will be done in the following directions: a gross domestic product will be created in the conditions of market relations, as a result of service, irrespective of creating or non-creating a material wealth. Therefore, it is expedient to look at services not from the point of view of the creation of material wealth, but from the point of view of the creation of gross domestic product.

In the modern era of development of social and service sectors, the provision of services is gaining popularity. Therefore, the labor efficiency per unit of achieved output is required to be able to calculate fixed assets, material and financial costs.

Production and services have long been a part of human economic activity, social community life. The interaction among people as a social community institution of services, the existence of useful activities - are considered 
necessary condition of society and life of human. It should be noted that it is not exaggeration if we say that services will increase the level of development of society, not only at the level of its productive forces, but also taking into account its spiritual and enlightenment status.

In this study, we will mark public service sectors as a system by improving the development models of public service sectors as a basis for systematic analysis. At the same time, we consider a single object and the types of services as a collection of collected elements in order to achieve the goal. Namely, we will systematically study to increase the efficiency of public services and living conditions. These researched types of services are understood as interconnected integrity in their integrity. As a result of systematic analysis, the economic-effectiveness indicator will be determined.

If we consider the process as a system in the modeling of service sectors, we must choose the main influencing factors, namely, input indicators. When modeling a process, we will choose the type or appearance of the model to be generated, if we choose which type of service sector. It is not impossible to take into account all factors in modeling, so we must choose the main influencing factors and take into account the ongoing socio-economic reforms which have been carried out in this field. The outcome factor and evaluation criteria are determined from the generated model (Figure 2).

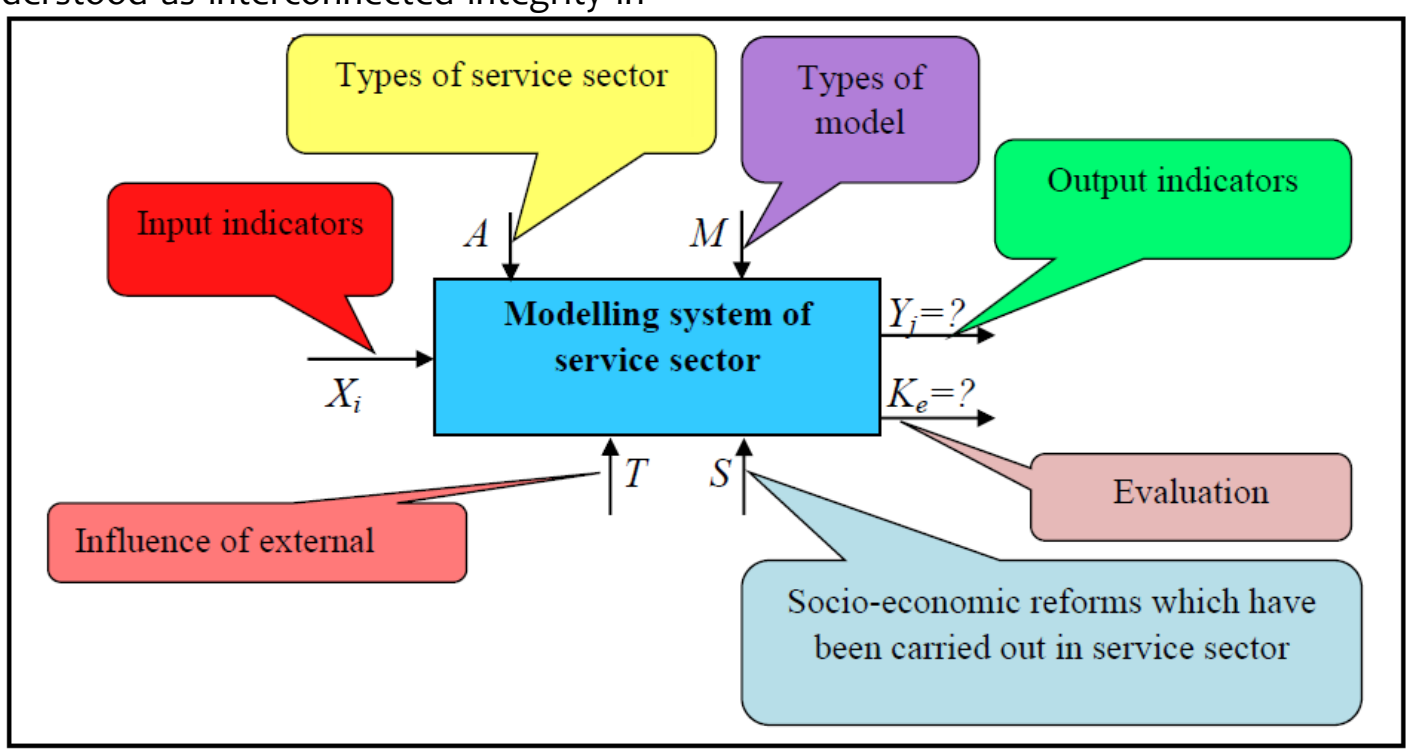

Figure 2. Systematic analysis, synthesis and optimization in the modeling of service sectors

It should be noted that the attitude of the population to the service sector is formed in the conditions of social ownership to production tools, a single centralized system of economic movement, limited economic independence of enterprises.

In the condition of market economy, service enterprises operate in a variety of forms of ownership, full economic independence and competitiveness. This market involves the flexible use of different methods of house holding management and the choice of econometric models of service, in this case, it

creates opportunity for rapid adaptation to changes in the external environment in a competitive environment.

Our goal consists of analyzing the service 
sectors in the region and improving its models.

I. First of all, modeling gives opportunity to express a large and complex system using a simple model. The process of providing services to the population is a very complex system. It can be expressed through a systematic analysis scheme (Figure 2 ).

The mechanism of public service can be described graphically. Of course, this creates many problems.

II. The wide field is created for making experiments with the structure of the econometric model of public service sectors. We can determine the most optimal state of activity of service enterprises by changing several times the parameters of the model. We can experiment on electronic computing machines through this model and then we can apply it in life.

Experimenting on real objects can lead to many mistakes and huge costs.

III. The service sectors will be studied and analyzed in detail in order to create a model. After the model is created, it can be obtained new information about processes of service sector with using it. Thus, the process of service sector becomes a continuous process.

A systematic methodology of complex problems in the field of services is developed on the basis of a systematic approach and general concepts. During the analysis, we take into account the internal and external environment of the service sectors. This means that it must be taken into account not only internal factors, but also external factors such as economic, geopolitical, social, demographic, environmental and other factors.

Each system of the service sector includes its own service elements, while at the same time it reflects the low-level subsystem elements. In other words, the elements of the service sector will be interconnected with different systems in many ways, without interfering with each other.

The systematic approach is expedient for each element of its structural structure in ensuring the completeness of the public service system.

In order to do this, the service sector is considered as a complex system, quantitative and qualitative aspects of its expression laws are studied. Imitation has important role in the analysis of the activities of the service sector which is considered as a complex economic process.

The imitation model is constructed for each sector to predict the future state of the public service sector. The following tasks should be done in order to do this (Figure 3):

Forming database of service sector networks and factors which influence it;

Identifying the relationship between each service sector and the factors which influence it, the factors which influence it;

Developing a separate model for each service sector;

Examining developed models according to evaluation criteria;

Forming a database forecast on the basis of certain legitimacies of factors which influence forecasting through models which are considered significant;

Achieving outcome factors on the basis of databases and models. 


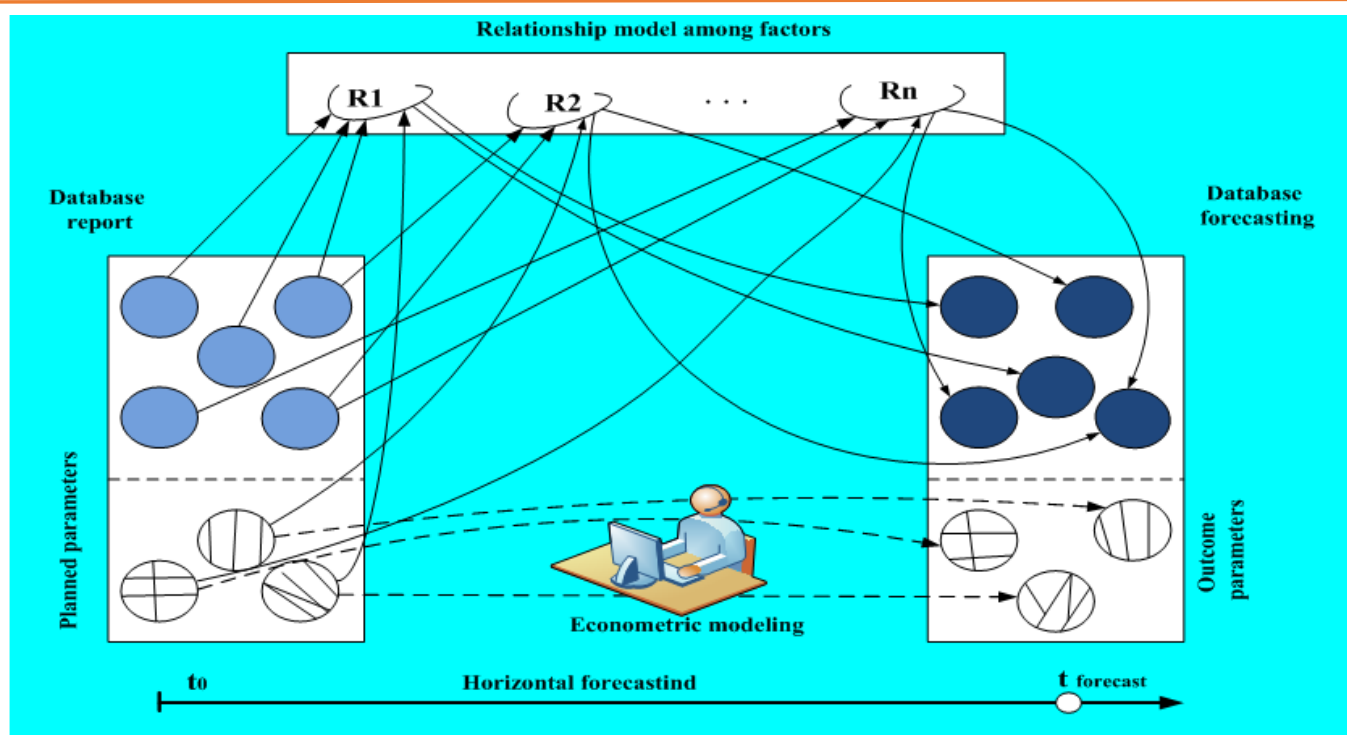

Figure 3. Scheme of systematic imitation of econometric modeling of the public service sector

In this case, special functions are reviewed, attention is paid to the algorithms of system operation. It is implied the properties which lead to the goal as function. In this case, performing functions of the system are evaluated on the basis of a functional approach. It creates opportunity to determine the activity of the system, to determine its status, to mark the management legitimacies of systems. An important aspect of this is considered appearing hierarchical subordination among these parts and reflecting it in the relative independence of these parts. This will help the population to develop an integrated systematic imitation model of all elements of its service sector on the basis of a single system.

It is expedient to study the correspondence of different values to the factors which influence to the social phenomena, not the same values, and the correlation connection of their interdependence. Because a characteristic feature of the social spheres is that it is impossible to determine a complete list (strength) of all the factors which affect this sphere.

Besides, only approximate expressions of the connections can be written using the formula. Because the number of factors which influence the living conditions of the population is so large, it is impossible to determine a complete list of them and write an equation which fully represents the connection with influencing outcome sign.

The development of the living conditions of the population is considered so incompletely connection, that different values of the results of the factor which influence it in the different time and space, correspond to each value of the factors. Hence, the total number of influencing factors will be unknown. It is expedient to study such a dependence through correlation connections.

Our task consists of evaluating the existence of strong and weak connections which influence the development of public service sectors. We use the correlation analysis method in order to perform this task. Because our goal is considered to evaluate the importance and reliability of the interdependencies which influence the development of each sector which serves the population. We measure the criterion of dependence which influences the living 
The American Journal of Applied sciences

(ISSN - 2689-0992)

Published: February 20, 2021 | Pages: 21-48

conditions of the population through correlation analysis, but we cannot determine the cause of the relationships.

We selected information which belong to the reporting years 2004 - 2018, these information identified the areas of service and the factors which influence them, on the basis of certain signs (Table 1).

In this case, the factors which influence the development of each service sector are separately divided in the modeling. Therefore, we took the development of some service

\section{Table 1.}

sectors as a factor which influences to other service sectors. The impact of influencing factors affects service sectors in different degrees. Selected factors may be involved in modeling once or more. Because we consider one factor as the main factor which influences each service sector, and we can consider another factor as the main factor which influences only one service sector.

\section{Service sectors for the population of Kashkadarya region and the factors which influence them}

\begin{tabular}{|c|c|}
\hline $\begin{array}{l}A_{a a x} \text {-providing communication and information services to the population of the region } \\
\text { (in billion soums) }\end{array}$ & $\mathrm{Y}_{1}$ \\
\hline$M_{x}-$ providing financial services to the population of region (in billion soums) & $\mathrm{Y}_{2}$ \\
\hline$S_{x}-$ providing trade services to the population of the region (in billion soums) & $\mathrm{Y}_{3}$ \\
\hline$T_{t x}-$ providing transport services to the population of the region (in billion soums) & $\mathrm{Y}_{4}$ \\
\hline $\begin{array}{c}\mathrm{YjO}_{x} \text { - providing accommodation and food services to the population of the region (in } \\
\text { billion soums) }\end{array}$ & $\mathrm{Y}_{5}$ \\
\hline $\mathrm{Km}_{\mathrm{x}}-$ providing real estate services to the population of the region (in billion soums) & $\mathrm{Y}_{6}$ \\
\hline$T_{o^{\prime} x}-$ providing education services to the population of the region (in billion soums) & $\mathrm{Y}_{7}$ \\
\hline $\mathrm{SS}_{x}-$ providing health care services to the population of the region (in billion soums) & $\mathrm{Y}_{8}$ \\
\hline$I_{x}-$ providing rental services to the population of the region (in billion soums) & $Y_{9}$ \\
\hline$Y t_{x}-$ providing individual services to the population of the region (in billion soums) & $Y_{10}$ \\
\hline $\begin{array}{l}M K_{x}-\text { providing household goods and computer repair services to the population of the } \\
\text { region (in billion soums) }\end{array}$ & $Y_{11}$ \\
\hline $\begin{array}{l}T s M_{x}-\text { providing technical testing and architectural services to the population of the } \\
\text { region (in billion soums) }\end{array}$ & $Y_{12}$ \\
\hline$A_{s}-$ total number of the population of region (thousand people) & $\mathrm{X}_{1}$ \\
\hline$I_{b a}-$ employed part of the population of the region (thousand people) & $\mathrm{X}_{2}$ \\
\hline$A_{d}-$ total income of the population of region (in billion soums) & $X_{3}$ \\
\hline$U_{i}-$ total consumption of the population of the region (in billion soums) & $\mathrm{X}_{4}$ \\
\hline
\end{tabular}




\begin{tabular}{|c|c|}
\hline $\mathrm{SH}_{\mathrm{i}}$ - personal consumption of the population of the region (in billion soums) & $X_{5}$ \\
\hline$I_{i}$-social consumption of the population of the region (in billion soums) & $\mathrm{X}_{6}$ \\
\hline$K_{m}-$ capital investments of the population of the region (in billion soums) & $X_{7}$ \\
\hline$Q x_{m}-$ volume of regional agricultural production (in billion soums) & $\mathrm{X}_{8}$ \\
\hline$T_{a}-$ volume of regional trade turnover (in billion soums) & $X_{9}$ \\
\hline$C_{m}-$ volume of regional industrial production (in billion soums) & $X_{10}$ \\
\hline$Y_{t}-$ carriage of passengers in the region (thousand people) & $\mathrm{X}_{11}$ \\
\hline $\begin{array}{l}\mathrm{TFO}_{b x}-\text { total expenditures related to improving the welfare of the population of the } \\
\text { region (in billion soums) }\end{array}$ & $X_{12}$ \\
\hline$U_{y k_{x x}}$ - housing expenditures for the population of the region (in billion soums) & $X_{13}$ \\
\hline $\mathrm{O}_{s}^{\prime}-$ the number of teachers per thousand students in the region & $\mathrm{X}_{14}$ \\
\hline$S_{s x}-$ regional health care expenditures (in billion soums) & $\mathrm{X}_{15}$ \\
\hline $\mathrm{K}_{\mathrm{o}^{\prime} \mathrm{s}}-$ the number of hospital beds per 10,000 population in the region & $\mathrm{X}_{16}$ \\
\hline$V_{s}-$ the number of doctors per 10,000 population of the region & $X_{17}$ \\
\hline $\mathrm{H}_{\mathrm{s}}-$ the number of nurses per 10,000 population of the region & $\mathrm{X}_{18}$ \\
\hline Xtx - expenditures for public education in the region (in billion soums) & $X_{19}$ \\
\hline
\end{tabular}

For example, if the total income of the population of the region becomes factor which influences all service sectors, the expenditures for the regional health care will be considered the factor which only influences the development of the health care sector for the population of this region.

We created the following functional view on the basis of the service sectors in Table 1 and the factors which influence them (Table 2). 
Table 2.

\section{A functional view of the empirical models which are structured for each sector of the service sector for the population of the region}

\begin{tabular}{|c|c|}
\hline $\begin{array}{l}A_{a a x}-\text { providing communication and } \\
\text { information services to the population of the } \\
\text { region }\end{array}$ & $A_{\text {aax }}=\varphi_{1}\left(A_{s}, A_{d}, U_{i}\right)+\varepsilon_{1}$ \\
\hline $\begin{array}{l}M_{x}-\text { providing financial services to the } \\
\text { population of region }\end{array}$ & $M_{x}=\varphi_{2}\left(I_{b a}, K_{m}, S_{x}\right)+\varepsilon_{2}$ \\
\hline $\begin{array}{l}S_{x}-\text { providing trade services to the population } \\
\text { of the region }\end{array}$ & $S_{x}=\varphi_{3}\left(A_{s}, A_{d}, U_{i}, K_{m}, C_{m}, Q_{x m}\right)+\varepsilon_{3}$ \\
\hline $\begin{array}{l}T_{t x}-\text { providing transport services to the } \\
\text { population of the region }\end{array}$ & $T_{t x}=\varphi_{4}\left(I_{b a}, A_{d}, K_{m}, Q_{x m}\right)+\varepsilon_{4}$ \\
\hline $\begin{array}{l}\mathrm{YjO}_{\mathrm{x}} \text { - providing accommodation and food } \\
\text { services to the population of the region }\end{array}$ & $Y j O_{x}=\varphi_{5}\left(A_{s}, A_{d}, K_{m}, T F O_{b x}\right)+\varepsilon_{5}$ \\
\hline $\begin{array}{l}K m_{x}-\text { providing real estate services to the } \\
\text { population of the region }\end{array}$ & $K m_{x}=\varphi_{6}\left(A_{d}, K_{m}, U y k_{x x}, M_{x}\right)+\varepsilon_{6}$ \\
\hline $\begin{array}{l}T_{o^{\prime} x}-\text { providing education services to the } \\
\text { population of the region }\end{array}$ & $T_{o r x}=\varphi_{7}\left(O_{s}^{\prime}, T F O_{b x}, M K_{x}, X_{t x}\right)+\varepsilon_{7}$ \\
\hline $\begin{array}{l}\mathrm{SS}_{x} \text { - providing health care services to the } \\
\text { population of the region }\end{array}$ & $S S_{x}=\varphi_{\mathrm{8}}\left(S_{s x}, K_{o r s}, V_{s}, H_{s}\right)+\varepsilon_{\mathrm{8}}$ \\
\hline $\begin{array}{l}I_{x} \text { - providing rental services to the population } \\
\text { of the region }\end{array}$ & $I_{x}=\varphi_{9}\left(A_{s,} K m_{x}, K_{m}\right)+\varepsilon_{9}$ \\
\hline $\begin{array}{l}Y t_{x}-\text { providing individual services to the } \\
\text { population of the region }\end{array}$ & $Y t_{x}=\varphi_{10}\left(A_{s}, S H_{i}, K_{m}, I_{i}\right)+\varepsilon_{10}$ \\
\hline $\begin{array}{l}M K_{x} \text {-providing household goods and } \\
\text { computer repair services to the population of } \\
\text { the region }\end{array}$ & $M K_{x}=\varphi_{11}\left(A_{d}, S S_{x}, T_{o r x}\right)+\varepsilon_{11}$ \\
\hline $\begin{array}{l}T s M_{x}-\text { providing technical testing and } \\
\text { architectural services to the population of the } \\
\text { region }\end{array}$ & $T s M_{x}=\varphi_{12}\left(I_{b a}, A_{d}, T F O_{b x}\right)+\varepsilon_{12}$ \\
\hline
\end{tabular}

We used statistical data from 2004 to 2018 to create multifactoral empirical models through the service sectors for the population of Kashkadarya region and the factors which influence them. 
Table 3.

\section{Statistical data of the service sector of the population of Kashkadarya region}

\begin{tabular}{|c|c|c|c|c|c|c|c|c|c|c|c|}
\hline 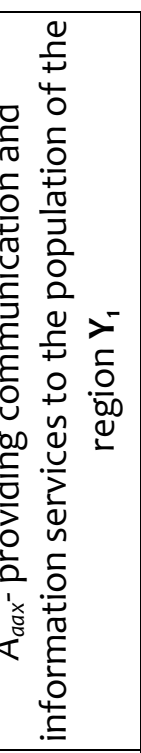 & 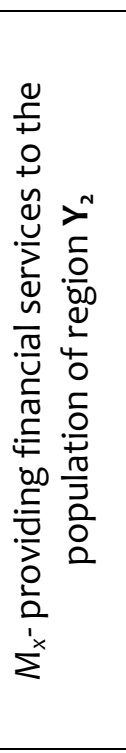 & 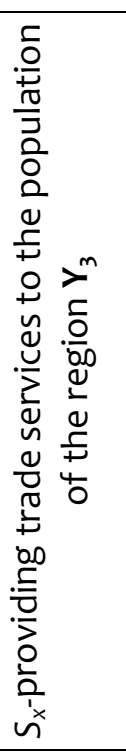 & 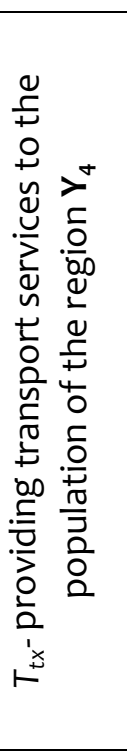 & 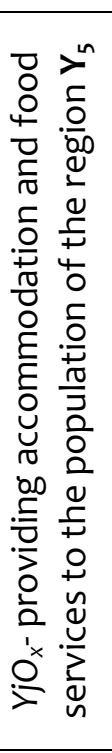 & 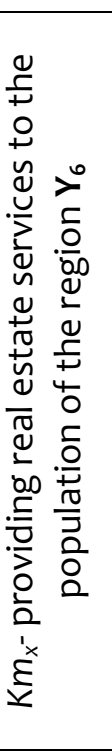 & 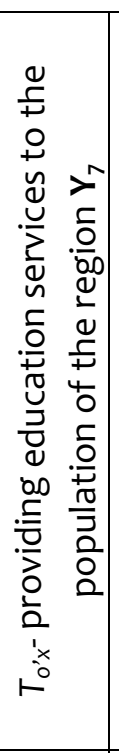 & 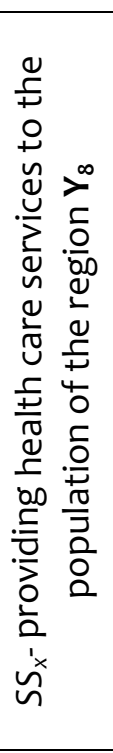 & 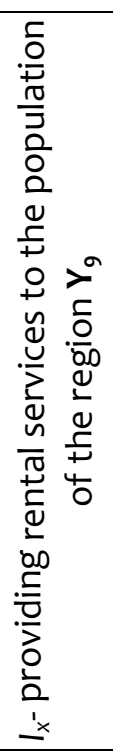 & 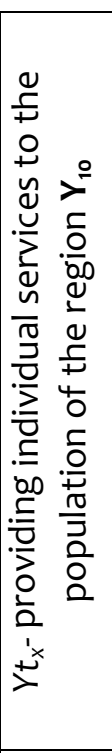 & 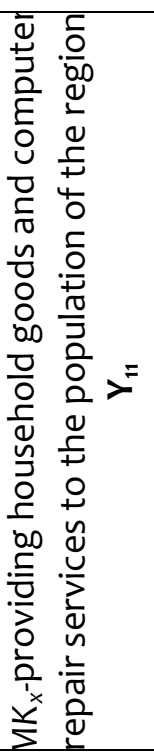 & 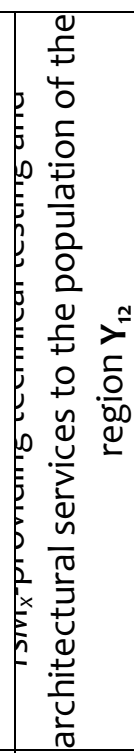 \\
\hline 8,7 & 16,6 & 83,9 & 18,3 & 7,9 & 5,4 & 3,9 & 2,4 & 7,6 & 13,5 & 4,7 & 4,9 \\
\hline 10,1 & 19,3 & 98,7 & 27,7 & 10,4 & 7,8 & 7,8 & 3,7 & 9,1 & 17,9 & 6,1 & 7,7 \\
\hline 17,9 & 26,3 & 116,1 & 34,04 & 17,2 & 12,4 & 11,9 & 4,3 & 12,3 & 20,4 & 7,6 & 9,1 \\
\hline 27,9 & 37,6 & 145,6 & 52,95 & 18,1 & 14,1 & 15,2 & 5,4 & 15,6 & 22,7 & 11,2 & 12,3 \\
\hline 48,8 & 62,2 & 192,7 & 80,39 & 18,9 & 18,3 & 18,9 & 7,9 & 16,3 & 28,9 & 20,7 & 14,7 \\
\hline 55,6 & 78,8 & 223,8 & 100,16 & 29,6 & 26,7 & 32,3 & 13,6 & 21,7 & 37,6 & 30,8 & 15,8 \\
\hline 89,4 & 83,1 & 312,6 & 143,3 & 31,4 & 31,4 & 39,3 & 16,4 & 29,7 & 57,1 & 48,4 & 20,3 \\
\hline 101,3 & 83,3 & 458,8 & 146,2 & 27,8 & 40,6 & 38,9 & 13,1 & 38,9 & 56,7 & 60,6 & 12,3 \\
\hline 131,9 & 103,4 & 734,4 & 166,4 & 26,3 & 63,7 & 46,2 & 14,8 & 44,8 & 78,3 & 61,8 & 16,9 \\
\hline 187,7 & 207,4 & 928,8 & 186,6 & 26,9 & 89,5 & 69,6 & 26,9 & 70,6 & 112,4 & 92,3 & 20,6 \\
\hline 241,2 & 254,2 & 1133,8 & 206,8 & 20,9 & 108,3 & 89,8 & 28,2 & 88,1 & 150,8 & 135,4 & 21,2 \\
\hline 274,8 & 312,9 & 1290,6 & 227,1 & 25,4 & 136,9 & 106,5 & 39,5 & 109,1 & 158,3 & 185,3 & 33,3 \\
\hline 328,7 & 412,8 & 1646,3 & 247,3 & 146,9 & 170,2 & 131,1 & 45,8 & 135,9 & 209,2 & 216,4 & 30,0 \\
\hline 370,6 & 566,9 & 1935,8 & 267,5 & 185,1 & 191,3 & 163,9 & 54,4 & 158,0 & 234,5 & 226,5 & 50,3 \\
\hline 426,1 & 787,4 & 2337,0 & 287,7 & 220,8 & 226,9 & 227,8 & 75,0 & 197,7 & 262,9 & 256,5 & 76,7 \\
\hline
\end{tabular}


Table 4.

Statistical data of the factors which influence the service sector networks of the population of Kashkadarya region

\begin{tabular}{|c|c|c|c|c|c|c|c|c|c|c|c|c|c|c|c|c|}
\hline 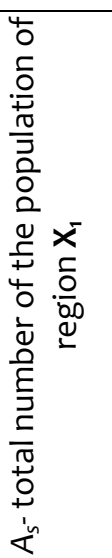 & 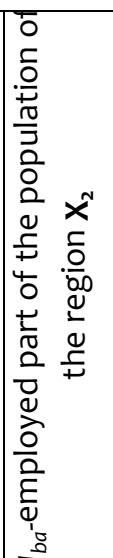 & 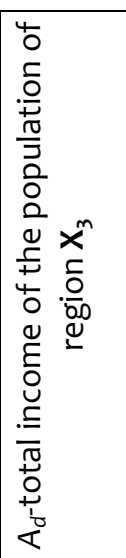 & 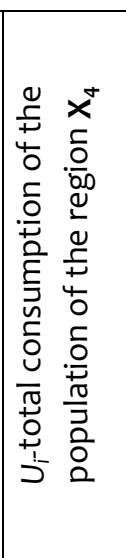 & 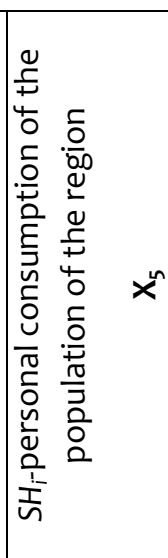 & 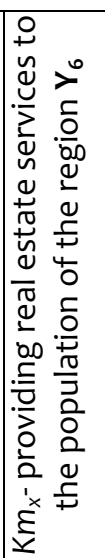 & 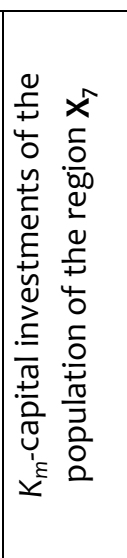 & 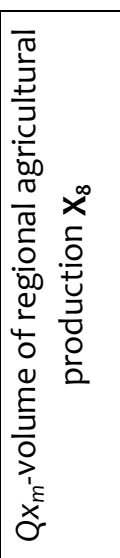 & 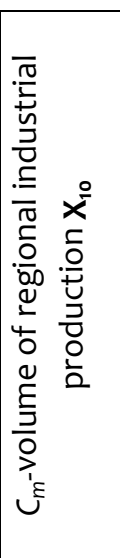 & 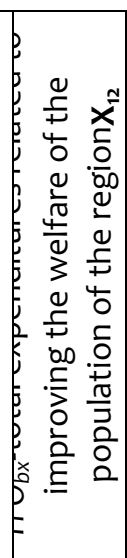 & 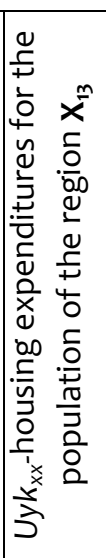 & 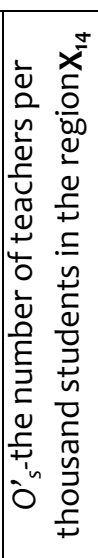 & 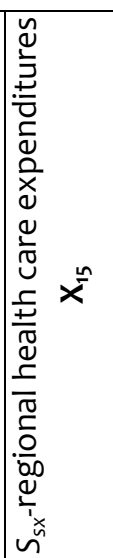 & 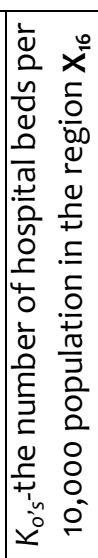 & 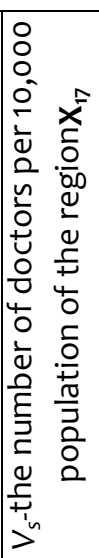 & 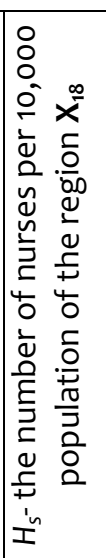 & 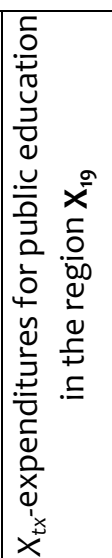 \\
\hline 2378,2 & 769,4 & 541,7 & 430,3 & 325 & 5,4 & 339,3 & 432,36 & 773,9 & 20,3 & 3,3 & 53,3 & 19,4 & 12,6 & 24,1 & 101,1 & 56,576 \\
\hline 2419,8 & 821,7 & 653,5 & 539,1 & 408,4 & 7,8 & 437,3 & 538,5 & 1375,3 & 26,1 & 3,3 & 53,9 & 25,5 & 12,6 & 24,1 & 100,3 & 75,139 \\
\hline 2462,2 & 850 & 850,3 & 701,75 & 535,7 & 12,4 & 697,9 & 670,63 & 1896,5 & 34,5 & 4,6 & 52,7 & 37,3 & 12,7 & 22,3 & 100,7 & 90,9 \\
\hline 2506,2 & 877,8 & 1068 & 877,8 & 660 & 14,1 & 830 & 796,13 & 2257,2 & 43,9 & 4,6 & 53,8 & 49,1 & 11,3 & 20,7 & 100,4 & 121,1 \\
\hline 2565,9 & 908,7 & 1376,6 & 1130,7 & 863,1 & 18,3 & 1630,7 & 949,9 & 3049,5 & 79,2 & 6,1 & 55,4 & 70,7 & 11,3 & 20,8 & 101,6 & 170,0 \\
\hline 2615,5 & 940,2 & 1803,4 & 1494,4 & 1145,1 & 26,7 & 2193 & 1079,8 & 4082,9 & 108,3 & 7,3 & 56,1 & 93,9 & 10,9 & 20,8 & 101,8 & 223,2 \\
\hline 2671 & 971,6 & 2380,4 & 1938,7 & 1468,7 & 31,4 & 1598 & 1329,8 & 3958,8 & 128,1 & 88,3 & 53,9 & 129,6 & 11 & 20,8 & 101,9 & 294,8 \\
\hline 2713,2 & 1003,7 & 2692,1 & 2199,4 & 1671,9 & 40,6 & 1802,8 & 1407,3 & 4759,2 & 127,3 & 97,8 & 52,7 & 166,9 & 11,1 & 20,8 & 101,9 & 369,0 \\
\hline 2762,3 & 1036,6 & 3186 & 2596,5 & 1973,1 & 63,7 & 2030,3 & 1552,1 & 5313,2 & 149,4 & 98,6 & 51,6 & 209,1 & 11 & 18,3 & 100,7 & 469,1 \\
\hline 2895,5 & 1072,3 & 3723,5 & 3027,4 & 2299,5 & 89,5 & 2257,6 & 1696,9 & 5862,3 & 136,5 & 98,7 & 49,8 & 255,9 & 11 & 18,3 & 100,7 & 557,6 \\
\hline 2958,9 & 1108,5 & 4304,4 & 3492,1 & 2651,3 & 108,3 & 2484,5 & 1841,7 & 6406,7 & 147,1 & 113,8 & 48,0 & 303,1 & 10,5 & 17,3 & 100,2 & 674,1 \\
\hline 3025,6 & 1143,9 & 4928,9 & 3990,5 & 3028,5 & 136,9 & 2711,4 & 1986,5 & 6946,2 & 165,6 & 140,8 & 47,0 & 342,9 & 10,5 & 16,6 & 100,2 & 746,1 \\
\hline 3089,4 & 1180,9 & 5597,1 & 4522,6 & 3431,1 & 170,2 & 2938 & 2131,3 & 7480,9 & 150,7 & 165,6 & 45,4 & 382,6 & 10,5 & 16,6 & 97,9 & 848,8 \\
\hline 3148,1 & 1218 & 6308,6 & 5088,6 & 3859,1 & 191,3 & 3164,5 & 2276,1 & 8010,7 & 165,6 & 198,4 & 47,3 & 466,1 & 9,8 & 15,9 & 98,2 & 984,9 \\
\hline 3186,8 & 1262,6 & 7063,8 & 5688,3 & 4312,5 & 226,9 & 3390,8 & 2420,6 & 8535,7 & 239,9 & 226,9 & 50,7 & 618,6 & 9,8 & 16,2 & 98,4 & 1331,9 \\
\hline
\end{tabular}

One of the main rules of constructing a multi-factorial empirical model is considered to determine the connection densities among the factors which are selected for the model, namely, to investigate the problem of multicollinearity of the connection among the selected factors. To do this, the correlation coefficients among the factors are calculated in order to do this, and when $x_{i}$ and $y_{i}$ variables accept the values of $i=1, \ldots, n$, they are considered the most common indicator which 
shows the linear relationship between $x$ and $y$, and the correlation coefficient. It is calculated as follows[25]:

$$
r_{x y}=\frac{\operatorname{Cov}(x, y)}{\sqrt{\operatorname{Var}(x)} \sqrt{\operatorname{Var}(y)}} .
$$

The value $\operatorname{Cov}(x, y)$ in the dividend of the fraction of equation (1) is determined by the following ratio:

$$
\operatorname{Cov}(x, y)=\frac{1}{n-1} \sum_{i=1}^{n}\left(x_{i}-\bar{x}\right)\left(y_{i}-\bar{y}\right)
$$

and it is called the covariance of the variables $x$ and $y$ and it is found as follows:

$$
\operatorname{Cov}(x, x)=\operatorname{Var}(x), \operatorname{Cov}(y, y)=\operatorname{Var}(y) .
$$

The correlation matrix among the factors which influence the development of each sector of the service sector in Kashkadarya region, was calculated in the program Eviews 9. For example, we have selected the number of teachers per thousand students in the region, the total expenditures of improving the living standards of the population of the region, the expenditures for public education in the region and providing household goods and computer repair services to the population of the region as factors which influence modeling quality education services. We carry out an autocorrelation analysis in order to determine if there is not multicollenity among these factors (Table 5).

Table 5.

\begin{tabular}{|c|c|c|c|c|c|}
\hline \multicolumn{2}{|c|}{ Covariance } & \multirow[b]{2}{*}{$\mathrm{X}_{14}$} & \multirow[b]{2}{*}{$X_{12}$} & \multirow[b]{2}{*}{$Y_{11}$} & \multirow[b]{2}{*}{$X_{19}$} \\
\hline & $Y_{7}$ & & & & \\
\hline$Y_{7}$ & 4010.294 & & & & \\
\hline Correlation & 1.000000 & & & & \\
\hline $\mathrm{t}$-Student criteria & ---- & & & & \\
\hline Probability & ---- & & & & \\
\hline$X_{14}$ & -138.6083 & 10.00907 & & & \\
\hline Correlation & -0.691838 & 1.000000 & & & \\
\hline $\mathrm{t}$-Student criteria & -3.454672 & ----- & & & \\
\hline Probability & 0.0043 & ---- & & & \\
\hline$X_{12}$ & 3329.935 & -111.4473 & 3648.468 & & \\
\hline
\end{tabular}

Correlation matrix among factors which influence the educational service sector to the population of the region 
The American Journal of Applied sciences

(ISSN - 2689-0992)

Published: February 20, 2021 | Pages: 21-48

\begin{tabular}{|l|c|c|c|c|c|}
\hline Correlation & 0.870547 & -0.583200 & 1.000000 & & \\
\hline t-Student criteria & 6.378583 & -2.588556 & ---- & & \\
\hline Probability & 0.0000 & 0.0225 & ---- & & \\
\hline$Y_{11}$ & 5322.235 & -225.5928 & 4488.000 & 7498.544 & \\
\hline Correlation & 0.970549 & -0.623455 & 0.558043 & 1.000000 & \\
\hline t-Student criteria & 14.52601 & -5.232830 & 6.023860 & ---- & \\
\hline Probability & 0.0000 & 0.0002 & 0.0000 & ---- & \\
\hline$X_{19}$ & 23178.60 & -871.1318 & 20535.46 & 31352.95 & 137403.0 \\
\hline Correlation & 0.987418 & -0.542829 & 0.717173 & 0.776769 & 1.000000 \\
\hline t-Student criteria & 22.51411 & -4.000576 & 8.298609 & 16.43436 & ---- \\
\hline Probability & 0.0000 & 0.0015 & 0.0000 & 0.0000 & -- \\
\hline
\end{tabular}

All above-mentioned factors are taken in order to create a multifactorial empirical model on the factors which influence the development of each sector of the public service sector, and it is examined how their importance are in the model.

It is expedient to use a linear and hierarchical multifactorial econometric model on the basis of its evaluation criteria according to its condition for each sector of the service sector.

We use the least squares method to construct and analyze an econometric model between public service sectors and the factors which influence them.

The linear multi-factorial econometric model has the following view:

$$
Y=a_{0}+a_{1} x_{1}+a_{2} x_{2}+\cdots+a_{n} x_{n}
$$

Here: $y$ - the outcome factor; $x_{1}, x_{2}, \ldots, x_{n}$ - Influencing factors.

The following system of normal equations is constructed to find the unknown parameters $a_{0}, a_{1}, a_{2}, \ldots$ , $a_{n}$ in the model (4):

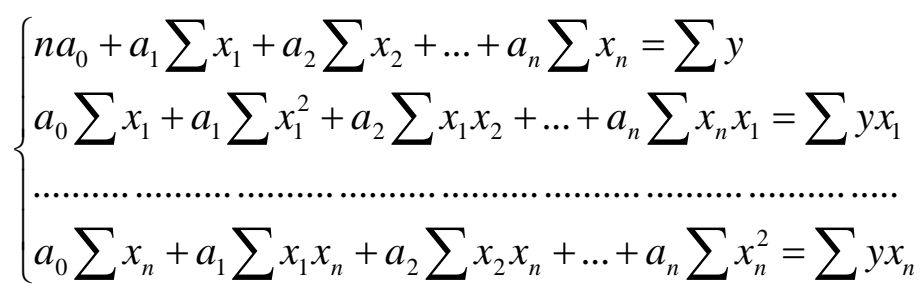

The hierarchical multi-factorial econometric model has the following view: 


$$
Y=a_{0} * x_{1}^{a_{1}} * x_{2}^{a_{2}} * \cdots * x_{n}^{a_{n}}
$$

Here: $y$ - the outcome factor; $x_{1}, x_{2}, \ldots, x_{n}$ - Influencing factors.

If we take the substitution in the model (6) by the natural logarithm, then we have the following view:

$$
\ln (y)=\ln \left(a_{0}\right)+a_{1} \ln \left(x_{1}\right)+a_{2} \ln \left(x_{2}\right)+\ldots+a_{n} \ln \left(x_{n}\right) .
$$

In model (7), if we make the definitions $\ln (y)=y^{\prime}, \ln \left(a_{0}\right)=a_{0}^{\prime}$, $\ln \left(x_{1}\right)=x_{1}^{\prime}, \ln \left(x_{2}\right)=x_{2}^{\prime}, \ldots, \ln \left(x_{n}\right)=x_{n}^{\prime}$ then we get the following view:

$$
y^{\prime}=a_{0}^{\prime}+a_{1} x_{1}^{\prime}+a_{2} x_{2}^{\prime}+\ldots+a_{n} x_{n}^{\prime} .
$$

The following system of normal equations is constructed to find the unknown parameters $a_{0}, \grave{a}_{1}, \ldots, \grave{a}_{n}$ in the model (8):

$$
\left\{\begin{array}{c}
n \grave{a}_{0}+\grave{a}_{1} \sum x_{1}^{\prime}+\grave{a}_{2} \sum x_{2}^{\prime}+\cdots \grave{a}_{n} \sum x_{n}^{\prime}=\sum y^{\prime} \\
\grave{a}_{0} \sum x_{1}^{\prime}+a_{1} \sum x_{1}^{\prime 2}+\grave{a}_{2} \sum x_{1}^{\prime} x_{2}^{\prime}+\cdots \grave{a}_{n} \sum x_{1}^{\prime} x_{n}^{\prime}=\sum x_{1}^{\prime} y^{\prime} \\
\cdots \cdots \cdots \cdots \cdots \cdots \cdots \cdots \cdots \cdots \cdots \cdots \cdots \cdots \cdots \cdots \cdots \cdots \cdots \cdots \cdots \cdots \cdots \cdots \cdots \cdots \cdots \cdots \cdots \cdots \\
\grave{a}_{0} \sum x_{n}^{\prime}+\grave{a}_{1} \sum x_{n}^{\prime} x_{1}^{\prime}+\grave{a}_{2} \sum x_{n}^{\prime} x_{2}^{\prime}+\cdots \grave{a}_{n} \sum x_{n}^{\prime 2}=\sum x_{n}^{\prime} y^{\prime}
\end{array}\right.
$$

If this system of normal equations ( 9 ) is solved analytically by several methods of mathematics, then the values of the unknown parameters $a_{0}, \grave{a}_{1}, \ldots, \grave{a}_{n} a_{0}, \grave{a}_{1}, \ldots, a_{n}$ are found.

In order to have multi-factorial empirical models of the processes, several options were calculated in the Eviews 9 program and appropriate results were obtained. For example, builds an empirical model for providing quality educational services to the population of the region is built in table 6 and it is shown their importance using criteria in the evaluation of this model and its parameters.

If there is not autocorrelation in the residuals of the outcome factor, then the value of the calculated DW criterion will be around 2 . 
Table 6.

Build an empirical model to provide educational services to the population of the region

\begin{tabular}{|c|c|c|c|c|}
\hline \multicolumn{5}{|c|}{ Method: the least squares method } \\
\hline Variable & Model coefficients & Standard errors & t-student criteria & P-value \\
\hline $\mathrm{X}_{14}$ & 4.954385 & 0.660405 & 7.502044 & 0.0000 \\
\hline$X_{12}$ & -0.282665 & 0.047388 & -5.964887 & 0.0001 \\
\hline$Y_{11}$ & 0.320081 & 0.078184 & 4.093951 & 0.0022 \\
\hline $\mathrm{X}_{19}$ & 0.169310 & 0.019435 & 8.711392 & 0.0000 \\
\hline C & -263.7938 & 35.03946 & -7.528476 & 0.0000 \\
\hline $\begin{array}{l}\mathrm{R} \quad-\quad \text { determination } \\
\text { coefficient }\end{array}$ & 0.917418 & \multicolumn{2}{|c|}{$\begin{array}{l}\text { The average value of the } \\
\text { dependent variable }\end{array}$} & 66.87333 \\
\hline Flattened & & \multirow{2}{*}{\multicolumn{2}{|c|}{$\begin{array}{l}\text { The standard deviation of the } \\
\text { dependent variable }\end{array}$}} & \\
\hline $\begin{array}{l}\mathrm{R}-\text { - determination } \\
\text { coefficient }\end{array}$ & 0.906386 & & & 65.54955 \\
\hline $\begin{array}{l}\text { Standard error of } \\
\text { regression }\end{array}$ & 3.940818 & \multicolumn{2}{|c|}{ Akayke's information model } & 5.841855 \\
\hline $\begin{array}{l}\text { The sum of the squares } \\
\text { of the remains }\end{array}$ & $155 \cdot 3005$ & \multicolumn{2}{|c|}{ Schwartz's information model } & 6.077872 \\
\hline $\begin{array}{ll}\text { The value of the } \\
\text { maximum } & \text { similarity } \\
\text { function } & \end{array}$ & -38.81391 & \multicolumn{2}{|c|}{ Hannan-Quinn criter. } & 5.839341 \\
\hline F-Fisher criteria & 965.8553 & \multicolumn{2}{|c|}{ DW-Darwin-Watson criteria } & 2.369623 \\
\hline Prob(F-Fisher criteria) & 0.000000 & & & \\
\hline
\end{tabular}

It was determined that the value of the DW criterion which were calculated the empirical models which were constructed for each sector of the service sector was higher than the table value. This indicates that there is not autocorrelation in the residues of outcome factor. The Fisher and Student criteria were calculated and the calculated value was compared with the table values, the magnitude of it was determined that they were higher than the table values.

The results of the analysis of the empirical models constructed for each sector of the public service sector in the region are presented in Table 7. 
Table 7.

Empirical models which were built for each sector of the service sector to the population of the region

\begin{tabular}{|c|c|c|c|c|}
\hline № & The view of empirical models & $\mathrm{R}^{2}$ & $\mathrm{~F}$ & DW \\
\hline 1. & 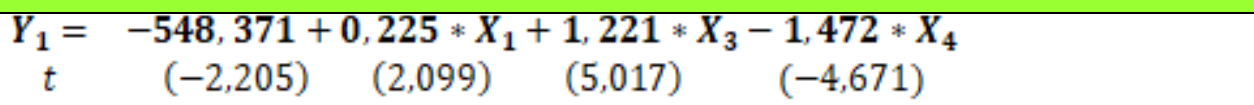 & 0.9165 & $1039 \cdot 591$ & 1.787 \\
\hline 2. & $\begin{array}{ccccc}Y_{2}= & 894,013-1,160 * X_{2}+0,075 * X_{7}+0,439 * Y_{3} \\
t & (2,267) & (-2,280) & (1,409) & (7,494)\end{array}$ & 0.9683 & 111.942 & 1.823 \\
\hline 3. & $\begin{array}{cl}Y_{3}= & e^{-48,222} * X_{3}^{43,490} * X_{4}^{-43,541} * X_{7}^{-1,165} * X_{10}^{4,796} * X_{8}^{-3,688} * X_{1}^{5,176} \\
t & (-3,263)(3,150)(-3,009)(-3,845)(3,191)(-2,715)(2,953)\end{array}$ & 0.9270 & 442.629 & 2.649 \\
\hline 4. & 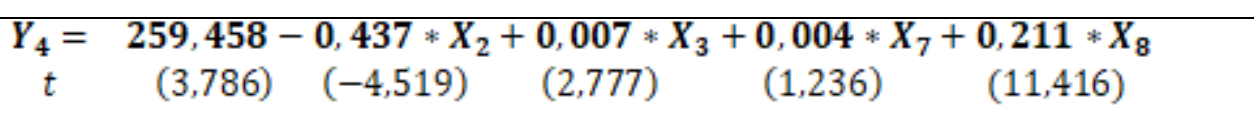 & 0.9092 & 3055.747 & 2.607 \\
\hline 5. & 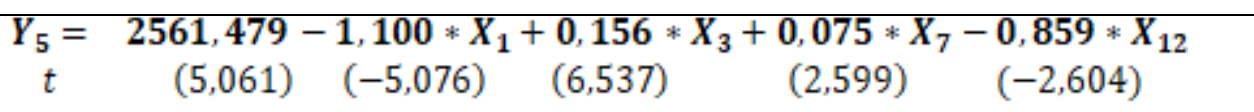 & 0.9196 & 28.601 & 1.894 \\
\hline 6. & 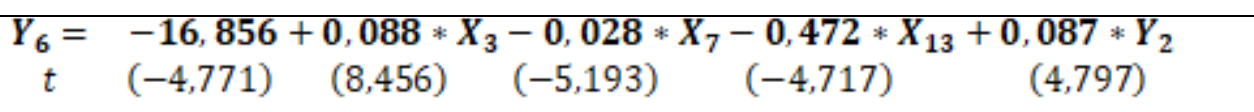 & 0.8971 & 863.141 & 1.909 \\
\hline 7. & $\begin{array}{ccccc}Y_{7}= & -263,794+4,954 * X_{14}-0,283 * X_{12}+0,320 * Y_{11}+0,169 * X_{19} \\
t & (-7,528) & (7,502) & (-5,965) & (4,094)\end{array}$ & 0.9174 & 965.855 & 2.370 \\
\hline 8. & 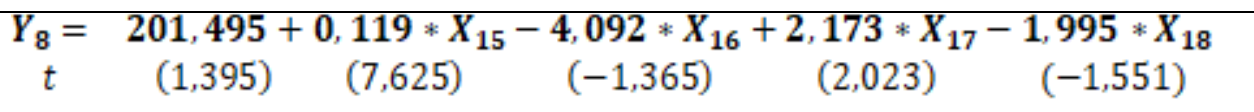 & 0.9014 & 131.693 & 2.023 \\
\hline 9. & $\begin{array}{c}Y_{9}=e^{-45,635} * X_{1}^{6,124} * Y_{6}^{0,457} * X_{7}^{-0,123} \\
t \\
(-4,033)(4,194)(3,231)(-1,849)\end{array}$ & 0.8978 & 1669.661 & 2.145 \\
\hline 10. & $\begin{array}{cc}Y_{10}= & e^{-67,604} * X_{1}^{8,708} * X_{5}^{1,550} * X_{7}^{-0,359} * X_{6}^{-0,932} \\
t & (-7,942)(7,664)(5,168)(-4,527)(-3,177)\end{array}$ & $\begin{array}{c}0.898 \\
4\end{array}$ & 1572.112 & 2.770 \\
\hline 11. & $\begin{array}{cc}Y_{11}= & e^{-9,051} * X_{2}^{1,732} * Y_{8}^{-0,552} * Y_{7}^{0,932} \\
t & (-7,448)(7,506)(-2,295)(2,435)\end{array}$ & $\begin{array}{c}0.886 \\
0\end{array}$ & 913.902 & 1.743 \\
\hline 12. & $\begin{aligned} Y_{12}= & e^{-84,125} * X_{2}^{14,959} * X_{3}^{-2,574} * X_{12}^{0,802} \\
t & (-4,571)(4,396)(-3,199)(2,628)\end{aligned}$ & 0.8842 & 62.095 & 2.428 \\
\hline
\end{tabular}

The parameters which were taken into account in the models which were built for each service sector (for linear regression equations) consist of different indicators. Therefore, it is necessary to calculate the coefficients of elasticity in the analysis. For example, we calculated the coefficients of elasticity in the analysis of the model built for the sector of communication and information services to the population of the region (Table 8). 
Table 8.

\section{Elasticity of model coefficients which were built for the sector of providing communication and information services to the population of the region}

\begin{tabular}{|c|c|c|c|}
\hline Variable & Model coefficients & Standardized coefficient & Elasticity coefficient \\
\hline X1 & 0.225065 & 0.437066 & 4.014907 \\
\hline X3 & 1.220895 & 18.55420 & 24.45173 \\
\hline X4 & -1.471871 & -17.99397 & -23.92220 \\
\hline C & -548.3712 & NA & -3.544434 \\
\hline
\end{tabular}

Analysis of the results of the multifactorial empirical model which is built for providing communication and information services to the population of the region $\left(Y_{1}\right)$ gives opportunity to determine the followings: if the total number of the population of the region $\left(X_{1}\right)$ increases by $1 \%$, providing communication and information services $\left(Y_{1}\right)$ will increase by $4,01 \%$, if the total income of the population of the region $\left(X_{3}\right)$ increases by $1 \%$, providing communication and information services $\left(Y_{1}\right)$ will increase by $24,45 \%$, if the total consumption of the population of the region $\left(X_{4}\right)$ increases by $1 \%$, providing communication and information services $\left(Y_{1}\right)$ will decrease by 23,92 percent.

Table 9.

Elasticity coefficient of the empirical model which was built to provide financial services to the population of Kashkadarya region

\begin{tabular}{|c|c|c|c|}
\hline \multicolumn{4}{|c|}{$M_{x}$ - model coefficients of providing financial services to the population of the region } \\
\hline Variable & Model coefficients & Standardized coefficient & Elasticity coefficient \\
\hline$X_{2}$ & -1.160381 & -0.768226 & -5.765751 \\
\hline$X_{7}$ & 0.074871 & 0.320796 & 0.699260 \\
\hline$Y_{3}$ & 0.438697 & 1.420181 & 1.672875 \\
\hline C & 894.0131 & NA & 4.393617 \\
\hline
\end{tabular}

The analysis of the elasticity coefficient of the parameters of the empirical model which is constructed in Table 9 shows that the analysis of the results of the multifactorial empirical model which is built for providing financial services sector $\left(Y_{2}\right)$ shows that if the employed part of the population of region $\left(X_{2}\right)$ increases by $1 \%$, the volume of providing financial services to them $\left(Y_{2}\right)$ will decrease by $5,77 \%$, the amount of capital investments of the population of the region $\left(X_{7}\right)$ will increase by $1 \%$, the volume of providing financial services to them $\left(Y_{2}\right)$ will increase by $0,70 \%$, the volume of providing trade services $\left(Y_{3}\right)$ will increase by $1 \%$, the volume of providing financial services $\left(Y_{2}\right)$ will increase by $1,67 \%$.

The results of the empirical model which is built for providing trade services to the population of the region $\left(Y_{3}\right)$ show that the volume of trade services to the population of the region $\left(Y_{3}\right)$ will increase 
by $5,18 \%$, if the total number of the population of the region $\left(X_{1}\right)$ increases by $1 \%$, if the total income of the population of the region $\left(X_{3}\right)$ increases by $1 \%$, the volume of trade services to the population of the region $\left(Y_{3}\right)$ will increase by $43,49 \%$, volume of total consumption of the population of the region $\left(X_{4}\right)$ increases by $1 \%$, the volume of trade services to the population of the region $\left(Y_{3}\right)$ will decrease by $43,54 \%$, if capital investment of the population of the region $\left(X_{7}\right)$ increases by $1 \%$, the volume of trade services to the population of the region $\left(Y_{3}\right)$ will decrease by $1,17 \%$, if the volume of regional industrial production $\left(X_{10}\right)$ increases by $1 \%$, the volume of trade services to the population of the region $\left(Y_{3}\right)$ will increase by $4,8 \%$, and if the amount of regional agricultural production $\left(X_{8}\right)$ increases by $1 \%$, the volume of trade services to the population of the region $\left(Y_{3}\right)$ will decrease by $3,69 \%$.

Table 10.

Elasticity coefficient of the empirical model which is built to provide transport services to the population of Kashkadarya region

\begin{tabular}{|c|c|c|c|}
\hline \multicolumn{4}{|c|}{$T_{t x}$ - model coefficients of providing transport services to the population of the region } \\
\hline Variable & Model coefficients & Standardized coefficient & Elasticity coefficient \\
\hline X2 & -0.437099 & -0.729789 & -3.023574 \\
\hline X3 & 0.007434 & 0.175785 & 0.157604 \\
\hline X7 & 0.004336 & 0.046857 & 0.056382 \\
\hline X8 & 0.211298 & 1.508453 & 2.034459 \\
\hline C & 259.4577 & NA & 1.775130 \\
\hline
\end{tabular}

The analysis of the elasticity coefficient of the parameters of the empirical model which is built in Table 10 shows that the multifactorial empirical model which is built for providing transport services to the population of the region $\left(Y_{4}\right)$ gives the following results: if employed part of the population of the region $\left(X_{2}\right)$ increases by $1 \%$, the volume of providing transport services to the population of the region $\left(Y_{4}\right)$ will decrease by $3,02 \%$, if the total income of the population of the region $\left(X_{3}\right)$ increases by $1 \%$, the volume of providing transport services to the population of the region $\left(Y_{4}\right)$ will increase by $0,16 \%$, capital investment of the population of the region $\left(X_{7}\right)$ increase by $1 \%$, providing transport services to the population of the region $\left(Y_{4}\right)$ will increase by $0,06 \%$, if the volume of regional agricultural production $\left(X_{8}\right)$ increase by $1 \%$, the volume of providing transport services to the population of the region $\left(Y_{4}\right)$ will increase by $2,03 \%$.

Table 11.

Elasticity coefficient of the empirical model which is built to provide accommodation and food services to the population of Kashkadarya region

$\mathrm{YjO}_{\mathrm{x}}$ - model coefficients of providing accommodation and food services to the population of the region 
The American Journal of Applied sciences

(ISSN - 2689-0992)

Published: February 20, 2021 | Pages: 21-48

\begin{tabular}{|c|c|c|c|}
\hline Variable & Model coefficients & Standardized coefficients & Elasticity coefficient \\
\hline X1 & -1.100206 & -4.369932 & -55.98207 \\
\hline X3 & 0.156436 & 4.862546 & 8.936691 \\
\hline X7 & 0.075311 & 1.069777 & 2.638688 \\
\hline X12 & -0.858810 & -0.777640 & -1.818216 \\
\hline C & 2561.479 & NA & 47.22490 \\
\hline
\end{tabular}

The results of Table 11 show that the multifactorial empirical model which is built with taking into account the factors which influence providing accommodation and food services to the population of the region $\left(Y_{5}\right)$, gives the following results: if total number of the population of the region $\left(X_{1}\right)$ increases by $1 \%$, providing accommodation and food services to the population of the region $\left(Y_{5}\right)$ will decrease by $55,98 \%$, the total income of the population of the region $\left(X_{3}\right)$ increases by $1 \%$, providing accommodation and food services to the population of the region $\left(Y_{5}\right)$ will increase by $8,94 \%$, the capital investment of the population of the region $\left(X_{7}\right)$ increases by $1 \%$, providing accommodation and food services to the population of the region $\left(Y_{5}\right)$ will increase by $2,64 \%$, if total expenditure of improving welfare of the population of the region $\left(X_{12}\right)$ increases by $1 \%$, providing accommodation and food services to the population of the region $\left(Y_{5}\right)$ will decrease by $1,82 \%$.

The multifactorial empirical model which is built for providing services related to the real estate services sector to the population of the region $\left(Y_{6}\right)$ gives the following results: if total income of the population of the region increase 1 billion soums, providing services related to the real estate services sector to the population of the region $\left(Y_{6}\right)$ will increase 0,088 billion soums, if the capital investments of the population of the region $\left(X_{7}\right)$ increases 1 billion soums, providing services related to the real estate services sector to the population of the region $\left(Y_{6}\right)$ will decrease 0,028 billion soums, if housing expenditures to the population of the region $\left(X_{13}\right)$ increases 1 billion soums, providing services related to the real estate services sector to the population of the region $\left(Y_{6}\right)$ will increase 0,472 billion soums and if providing financial services to the population of the region $\left(Y_{2}\right)$ increases 1 billion soums, providing services related to the real estate services sector to the population of the region $\left(Y_{6}\right)$ will increase 0,087 billion soums.

Table 12.

Elasticity coefficient of the empirical model which is built to provide educational services to the population of Kashkadarya region

\begin{tabular}{|c|c|c|c|}
\hline \multicolumn{4}{|c|}{$T_{0^{\prime} x^{-}}$model coefficients of providing education services to the population of the region } \\
\hline Variable & Model coefficients & Standardized coefficient & Elasticity coefficient \\
\hline $\mathbf{X}_{14}$ & 4.954385 & 0.247513 & 3.810989 \\
\hline $\mathbf{X}_{12}$ & -0.282665 & -0.269612 & -0.485385 \\
\hline $\mathbf{Y}_{11}$ & 0.320081 & 0.437684 & 0.435337 \\
\hline $\mathbf{X}_{19}$ & 0.169310 & 0.991042 & 1.183737 \\
\hline
\end{tabular}




\begin{tabular}{|c|c|c|}
\hline C & -263.7938 & \\
\hline
\end{tabular}

parameters of the empirical model which is built in Table 12 show that the multifactorial empirical model which is built for the development of educational services to the population of the region $\left(Y_{7}\right)$ gives the following results: if the number of teachers per thousand students in the region $\left(X_{14}\right)$ increases by $1 \%$, the volume of providing educational services to the population of the region $\left(Y_{7}\right)$ will increase by $3,81 \%$, if total expenditures related to improving the welfare of the population of the region $\left(X_{12}\right)$ increases by $1 \%$, the volume of providing educational services to the population of the region $\left(Y_{7}\right)$ will decrease by $0,49 \%$, if the amount of providing household goods and computer repair services $\left(Y_{11}\right)$ increases by $1 \%$, the volume of providing educational services to the population of the region $\left(Y_{7}\right)$ will increase by $0,44 \%$, and if the amount of expenditures for public education in the region $\left(X_{19}\right)$ increases by $1 \%$, the volume of providing educational services to the population of the region $\left(Y_{7}\right)$ will increase by $1,18 \%$.

The multifactorial empirical model which is built in order to develop the health care service sector to the population of the region $\left(Y_{8}\right)$ gives the following results: if the regional expenditure of health care service sector to the population of the region $\left(X_{15}\right)$ increases by $1 \%$, providing health care service sector to the population of the region $\left(Y_{8}\right)$ will increase $1,07 \%$, if the number of hospital beds per 10,000 population $\left(X_{16}\right)$ increase by $1 \%$, providing health care service sector to the population of the region $\left(Y_{8}\right)$ will decrease by $1,94 \%$, if the number of doctors per 10,000 population $\left(X_{17}\right)$ increase by $1 \%$, providing health care service sector to the population of the region $\left(Y_{8}\right)$ will increase by $1,82 \%$, if the number of nurses per 10,000 population $\left(X_{18}\right)$ increases by $1 \%$, and providing health care service sector to the population of the region $\left(Y_{8}\right)$ will decrease by $8,55 \%$.
The multifactorial empirical model which is built for providing rental services to the population of the region $\left(Y_{9}\right)$ gives the following results: if total number of the population of the region increases by $1 \%$, the volume of providing rental services to the population of the region $\left(Y_{9}\right)$ will increase by $6,124 \%$, if providing real estate services to the population of the region increases by $1 \%$, providing rental services to the population of the region $\left(Y_{9}\right)$ will increase by $0,457 \%$, if capital investments of the population of the region increases by $1 \%$, providing rental services to the population of the region $\left(Y_{9}\right)$ will increase and if the capital investment of the population of the region $\left(X_{7}\right)$ increases by $1 \%$, providing rental services to the population of the region $\left(Y_{9}\right)$ will increase by $0,123 \%$.

The empirical model which is built for providing individual services to the population of the region $\left(Y_{10}\right)$ gives the following result: if total number of the population of the region $\left(X_{1}\right)$ increases by $1 \%$, providing individual services to the population of the region $\left(Y_{10}\right)$ will increase by $8,71 \%$, if personal consumption of the population of the region $\left(X_{5}\right)$ increases by $1 \%$, providing individual services to the population of the region $\left(Y_{10}\right)$ will increase by $1,55 \%$, capital investments of the population of the region $\left(X_{7}\right)$ increases by $1 \%$, providing individual services to the population of the region $\left(Y_{10}\right)$ will decrease by $0,34 \%$, and social consumption of the population of the region $\left(X_{6}\right)$ increases by $1 \%$, providing individual services to the population of the region $\left(Y_{10}\right)$ will decrease by $0,93 \%$.

The multifactorial empirical model which is built for providing household goods and computer repair services $\left(Y_{11}\right)$ to the population of the region gives the following results: If total income of the population of the region $\left(X_{3}\right)$ increases by $1 \%$, the volume of providing household goods and computer repair services $\left(Y_{11}\right)$ will increase by $1,73 \%$. If the volume of health care services to the 
population of the region $\left(Y_{8}\right)$ increases by $1 \%$, the volume of providing household goods and computer repair services $\left(Y_{11}\right)$ will decrease by $0,55 \%$. If the volume of providing education services provided to the population of the region $\left(Y_{7}\right)$ increases by $1 \%$, and providing household goods and computer repair services to the population of the region $\left(Y_{11}\right)$ will increase by $0,55 \%$.

The multifactorial empirical model which is built for providing technical testing and architectural services for the population of the region $\left(Y_{12}\right)$ gives the following results: if the employed part of the population of the region increases by $1 \%$, the amount of providing technical testing and architectural services $\left(Y_{12}\right)$ for the population of the region will increase $14,96 \%$, if the total income of the population of the region $\left(X_{3}\right)$ increases by $1 \%$, the amount of providing technical testing and architectural services $\left(Y_{12}\right)$ for the population of the region will decrease by $2.57 \%$, and if the total expenditure of the population of the region $\left(X_{12}\right)$ increases by $1 \%$, the amount of providing technical testing and architectural services $\left(Y_{12}\right)$ for the population of the region will increase by $0,8 \%$.

In this regard, the method of econometric modeling was used in order to obtain the planning values of service sectors in the region, and it was made forecast.

We achieved the following efficiency when we analysed them with empirical models: As we can see from the table 13, the consistent implementation of the priorities which was set out in the Decree of our President "On the Action Strategy for the five priority areas of development of the Republic of Uzbekistan in 2017-2021", empirical models which is built in order to develop service sector to the population of Kashkadarya region in the future and forecasting results which are obtained with taking into account the ongoing reforms in this sector, show the followings:

Table 13.

Forecast of service sectors for the population of Kashkadarya region (billion soums / thousand soums)

\begin{tabular}{|c|c|c|c|c|c|c|c|}
\hline \multirow{2}{*}{ Indicators } & \multirow{2}{*}{$\begin{array}{l}2019 \\
\text { (real) }\end{array}$} & \multicolumn{6}{|c|}{ Forecast years } \\
\hline & & 2020 & 2021 & 2022 & 2023 & 2024 & 2025 \\
\hline \multirow{2}{*}{$\begin{array}{c}A_{a a x}-\text { providing communication } \\
\text { and information services to the } \\
\text { population of the region } Y_{1} / \text { per } \\
\text { capita }\end{array}$} & 478,29 & 538,79 & 602,84 & 670,41 & 741,52 & 816,2 & 894,4 \\
\hline & 147,27 & 162,84 & 178,90 & 195,42 & 212,37 & 229,7 & 247,5 \\
\hline \multirow{2}{*}{$\begin{array}{c}M_{x}-\text { providing financial services } \\
\text { to the population of the region } \\
Y_{2} / \text { per capita }\end{array}$} & 873,85 & 1060,11 & 1271,19 & 1508,83 & 1774,67 & 2484,0 & 3902,2 \\
\hline & 269,06 & 320,40 & 377,24 & 439,81 & 508,26 & 699,2 & 1079,9 \\
\hline \multirow{2}{*}{$\begin{array}{l}\mathrm{S}_{\mathrm{x}} \text { - providing trade services to } \\
\text { the population of the region } \mathrm{V}_{3} / \\
\text { per capita }\end{array}$} & 2761,5 & 3252,32 & 3801,25 & 4412,25 & 5089,09 & 5836,1 & 6657,1 \\
\hline & 850,29 & 982,95 & 1128,07 & 1286,11 & 1457,49 & 1642,7 & 1842,2 \\
\hline \multirow{2}{*}{$\begin{array}{l}T_{t x}-\text { providing transport } \\
\text { services to the population of } \\
\text { the region } \mathrm{Y}_{4} / \text { per capita }\end{array}$} & 306,07 & 327,07 & 348,19 & 369,44 & 390,82 & 412,3 & 434,0 \\
\hline & 94,24 & 98,85 & 103,33 & 107,69 & 111,93 & 116,1 & 120,1 \\
\hline
\end{tabular}


The American Journal of Applied sciences

(ISSN - 2689-0992)

\begin{tabular}{|c|c|c|c|c|c|c|c|}
\hline \multirow{2}{*}{$\begin{array}{c}\mathrm{YjO}_{x}-\text { providing } \\
\text { accommodation and food } \\
\text { services to the population of } \\
\text { the region } \mathrm{Y}_{5} / \text { per capita }\end{array}$} & 290,21 & 349,47 & 411,72 & 476,48 & 543,25 & 611,5 & 680,8 \\
\hline & 89,36 & 105,62 & 122,18 & 138,89 & 155,59 & 172,1 & 188,4 \\
\hline \multirow{2}{*}{$\begin{array}{l}\mathrm{Km}_{\mathrm{x}}-\text { providing real estate } \\
\text { services to the population of } \\
\text { the region } \mathrm{Y}_{6} / \text { per capita }\end{array}$} & 533,06 & 603,86 & 679,97 & 761,53 & 848,70 & 977,6 & 1171,3 \\
\hline & 164,13 & 182,50 & 201,79 & 221,98 & 243,06 & 275,2 & 324,1 \\
\hline \multirow{2}{*}{$\begin{array}{l}T_{o^{\prime} x}-\text { providing education } \\
\text { services to the population of } \\
\text { the region } Y_{7} / \text { per capita }\end{array}$} & 287,90 & 380,64 & 501,95 & 657,77 & 854,66 & 1098,7 & 1397,6 \\
\hline & 88,65 & 115,04 & 148,96 & 191,73 & 244,77 & 309,3 & 386,7 \\
\hline \multirow{2}{*}{$\begin{array}{l}\mathrm{SS}_{\mathrm{x}}-\text { providing health care } \\
\text { services to the population of } \\
\text { the region } \mathrm{Y}_{8} / \text { per capita }\end{array}$} & 95,88 & 114,57 & 136,06 & 160,68 & 188,76 & 220,7 & 256,8 \\
\hline & 29,52 & 34,63 & 40,38 & 46,84 & 54,06 & 62,1 & 71,1 \\
\hline \multirow{2}{*}{$\begin{array}{l}I_{x} \text { - providing rental services to } \\
\text { the population of the region } Y_{9} / \\
\text { per capita }\end{array}$} & 312,30 & 367,90 & 431,48 & 503,96 & 586,34 & 691,5 & 828,95 \\
\hline & 96,16 & 111,19 & 128,05 & 146,90 & 167,93 & 194,6 & 229,4 \\
\hline \multirow{2}{*}{$\begin{array}{l}Y t_{x}-\text { providing individual } \\
\text { services to the population of } \\
\text { the region } Y_{10} / \text { per capita }\end{array}$} & 326,29 & 390,42 & 465,96 & 554,68 & 658,58 & 779,9 & 921,3 \\
\hline & 100,47 & 117,99 & 138,28 & 161,68 & 188,62 & 219,5 & 294,9 \\
\hline \multirow{2}{*}{$\begin{array}{l}M K_{x}-\text { providing household } \\
\text { goods and computer repair } \\
\text { services to the population of } \\
\text { the region } \mathrm{Y}_{11} / \text { per capita }\end{array}$} & 345,40 & 389,42 & 434,50 & 481,30 & 530,37 & 582,5 & 638,2 \\
\hline & 106,35 & 117,69 & 128,94 & 140,29 & 151,89 & 164,0 & 176,6 \\
\hline \multirow{2}{*}{$\begin{array}{l}T_{s} M_{x}-\text { providing technical } \\
\text { testing and architectural } \\
\text { services to the population of } \\
\text { the region } Y_{12} / \text { per capita }\end{array}$} & 77,50 & 100,95 & 132,97 & 176,77 & 236,76 & 319,0 & 431,6 \\
\hline & 23,86 & 30,51 & 39,46 & 51,52 & 67,81 & 89,8 & 119,4 \\
\hline
\end{tabular}

Providing communication and information services $\left(A_{a a x}\right)$ to the population of the region in 2020 will increase by 1,13 times compared to 2019, and by 1,87 times by 2025 . Development of information and communication technologies is necessary to have a positive impact on the processes which are taking place in civil society and in a market economy. Communications such as mobile communication, international, communication among cities, local communication, postal, telegraphic communication, television, Internet in the field of communication and information services, further development of high-tech services, expanding the list of new types of services, as well as improving the quality of services impact to increase service sector;

Providing financial services $(M x)$ to the population of the region is expected to increase by 1,21 times in 2020 compared to 2019 , and by 4,47 times by 2025 . Liberalization of monetary policy, expansion of crediting scale for investment projects, as well as reforms which are carried out by providing innovative services by financial institutions 
have contributed to the growth of financial services. Except services in insurance and pension, financial services have a significant share in the total volume of financial services. Mediation services in monetary sector consists of the largest share of financial services except insurance and pension services;

Providing trade services $\left(S_{x}\right)$ to the population of the region is expected to increase by 1,18 times in 2020 compared to 2019, and by 2,41 times by 2025 . The necessary legal bases for the activities of wholesale and exchange trade enterprises have been created in the Republic, the retail trade sector is actively developing with the use of modern information technologies. The volume of trade services makes up a significant part of the total volume of services which are provided in the economy. As the level of income of the population increases, the volume of consumer demand and trade turnover increases. retail services have a significant role in the structure of trade services, except the sale of cars and motorcycles;

Providing transport services $\left(T_{t x}\right)$ to the population of the region is expected to increase 1,07 times in 2020 compared to 2019, and 1,42 times by 2025 . The need of population for transport service sectors, such as rail, road, air and pipeline transport, is growing day by day. During the years of independence, great works have been done on the strategic development of the transport system in the country: transport independence has been ensured and a national system which is connecting all regions of the republic with each other, has been created. The efficient transport system which is created in our country is considered a factor in the development of foreign economic relations and integration with other countries;

To the population of the region:

Providing accommodation and catering services $\left(\mathrm{YjO}_{\mathrm{x}}\right)$ will increase by 1.20 times in 2020 compared to 2019, and by 2,35 times by 2025;

Providing real estate services $\left(K m_{x}\right)$ will increase by 1,13 times in 2020 compared to 2019 , and by 2,20 times by 2025 ;

Providing educational services $\left(T_{o^{\prime} x}\right)$ is forecasted to increase by 1,32 times in 2020 compared to 2019 , and by 4,85 times by 2025 ;

Providing health care services $\left(\mathrm{SS}_{\mathrm{x}}\right.$ ) to the population of the region is expected to increase by 1,19 times in 2020 compared to 2019 , and by 2,68 times by 2025 . Opportunities of population for medical examinations before being ill will be expanded, medical care works through ambulatory-polyclinic and pharmacy services will be improved. Supplied level of hospital beds, the number of doctors per 10,000 people will increase, and health care institutes will be better equipped with the necessary equipment and facilities;

To the population of the region:

The volume of providing rental services $\left(I_{x}\right)$ will increase by 1,18 times in 2020 compared to 2019 , and by 2,65 times by 2025 ;

The volume of providing individual services $\left(Y t_{x}\right)$ will be 1,20 times in 2020 higher than in 2019, and 2,82 times higher in 2025;

The volume of providing household goods and computer repair services $\left(M K_{x}\right)$ will increase by 1,13 times in 2020 compared to 2019, and by 1,85 times by 2025 ;

The volume of providing technical testing and architectural services $\left(T s M_{x}\right)$ will increase by 1,30 times in 2020 compared to 2019, and by 5,57 times by 2025 .

\section{CONCLUSIONS}

It is expedient to separate econometric modeling of each service sector. Because development of each sector of the service 
sector has a positive impact on development of another sector. Therefore, the use of econometric models in the form of interconnected equations system has particular importance in development of service sectors. Together with this, the organizational-economic mechanism of development of service sectors represents a hierarchical system of interconnected elements and groups (subjects, objects, principles, forms, methods and tools) at different levels, as well as their interrelationships, innovative infrastructure form relationships with market participants.

According to forecasts which was carried out, the total volume of services which are provided to the population of Kashkadarya region is expected to increase by 3,46 times by 2025 , at the expense of saving the current trend. Providing educational services sector is expected to increase by 4.85 times by 2025 compared to 2019, providing health care services sector is expected to increase by 2,68 times by 2025 .

It is expedient to pay essential attention to the innovation factor for the sustainable development of the service sector for the population of the region in the future. It is necessary to encourage innovative ideas and newly opened service sectors, to encourage the factors which create conditions for the development of high-quality service sectors for developing and organizing service sectors on the basis of innovation in the region.

It is necessary to econometrically model the management plans for the elimination of imperfections in the way of achieving the social goals which are set for the economic growth and living standards of the population and the development of the living conditions of the population. During 2017-2021 years (also, in next periods), it is expedient to develop long-term forecasts (2020-2025) in order to plan policy and projects which will be accepted as the part of action strategy of regional development of the region, plan technologic modernization and service sectors, intensive development of infrastructure, orient them to the welfare of the population.

In the current situation, the service sector to the population offers a variety of additional services, the main content of these services composed of releasing the population from the anxieties in living conditions, improving the quality of services and achieving to live in meaningful daily life.

As a result of the research, recommendations are made on forming the methodology and development goals of the service sector, choosing options for decision-making methods and evaluation criteria variants, developing optimal options.

\section{REFERENCES}

1. Annex 1 to the Decree of the President of the Republic of Uzbekistan No. 4947 of February 7, 2017 "Strategy of actions on five priority areas of development of the Republic of Uzbekistan for 2017-2021" .Lex.uz.

2. State program PF-6079 "Development strategies of the Republic of Uzbekistan until 2035" 5.10.2020

3. Introduction to the "digital" economy / subtotal. ed. A. V. Keshelava. Moscow: VNII Geosystems, 2017.28 p.

4. Белых А. А. Основы методологии прогнозирования и оценки эффективности информационных систем // Научный журнал КубГАУ. 2011. № 71(07). URL: http://ej.kubagro.ru/2011/07/pdf/42.pdf (дата обращения: 10.10.2018).

5. Кейнс Дж. Избранные произведение. Пер. с анг. - М.: Экономика, 1993. -436 с. Портер М. Международная.

6. конкуренция: пер. с англ. под ред. щепшина В.Д. - М.: Международные отношения, 1993.-886 с. 
7. Strassmann P. The business value of computers.New Canaan : The Information Economics Press,1990. 530 p.

8. David P. The dynamo and the computer: anhistorical perspective on the modern productivity paradox // The American Economic Review. 1990. Vol. 88. № 2. P. $355-361$.

9. Information Technology and the Corporation of the 1990s : research Studies / ed. by T. J. Allen, M. S. Scott Morton. New York ; Oxford : Oxford University Press, 1994.

10. Блиянц К. М. Особенности оценки эффективности информационных технологий в управленческой деятельности в АПК // Региональные проблемы преобразования экономики. 2016.№ 1. C. 38-43.

11. Васильева Е. В., Деева Е. А. Оценка экономической эффективности конкурирующих ИТ-проектов: подходы и математический инструментарий // Управление. 2017. № 4(18). С. 40-46.

12. Ермакова Ж. А., Парусимова Н. И., Пергунова О. В. Оценка экономической эффективности информационнокоммуникационных технологий на промышленных предприятиях // Вестник ОГУ.2014. № 1. С. 255一260.

13. Проектирование будущего. Проблемы цифровой реальности : тр. 1-й междунар. конф.,Москва, 8-9 февр., 2018 г. М. : ИПМ им. М. В. Келдыша, 2018. 174 с.

14. Сагынбекова А. С. Цифровая экономика:понятие, перспективы, тенденции развития в России // Теория. Практика. Инновации. 2018. № 4.URL: http://www.tpinauka.ru/2018/04/Sagynbek ova.pdf (дата обращения: 18.11.2018).

15. Гранберг А.Г. Основы региональной экономики.- М.: «Экономика», 2000. -346 с. Гаврилов А.И. Региональная экономика и управление.- М.: ЮНИТИ, 2002. $-239 \mathrm{C}$.

16. Рузметов Б. Оптимизационные задачи многоагрегатных комплексов. Модели, методы решения, программные модули. - Т.: Фан, 2010.

17. Arens R. Complex processes for envelopes of normal noise // IRE Trans. Inform. Theory, Sept. 1957, vol. IT-3, pp. 204-207.

18. Goodman N.R. Statistical analysis based on a certain multivariate complex Gaussian distribution // Ann. Math. Statist. 1963, vol. 34, p. 152-176. Wooding R. A. The multivariate distribution of complex normal variables // Biometrika, 1956, vol. 43, p. 212-215.

19. Tavares G. N., Tavares L. M. On the Statistics of the Sum of Squared Complex Gaussian Random Variables // IEEE Transactions on Communications, 55(32), 2007. - p. 1857-1862.

20. Афанасьев А.А., Пономарева О.С. Производственная функция народного хозяйства России в 1990-2012 гг. // Экономика и математические методы. 2014, 50 (26), 21-33.с.

21. Клейнер Г.Б. Мезоэкономика развития. - М.: Наука, 2011. - 806 с.

22. Svetunkov Sergey. Complex-Valued Modeling in Economics and Finance Springer Science + Business Media, New York, 2012. $-318 \mathrm{p}$.

23. Merkulova T.V., Prikhodko F.I. Dynamics of macroeconomic indicators modeling by functions of complex variables // БізнесІнформ (Бюлетень ВАК Украіни) // № 4 (5) 2010 (381). C. $67-71$.

24. http//www.statista.comm/statistics/27007 2/distribution-of-the-workforce.

25. Тараққиётнинг ўқ илдизи ёхуд хизмат кўрсатишнинг мамлакат имижини оширишдаги мухим роли хусусида //http://uza.uz/oz/business/-07-09-2019.

26. Эконометрика: учебник./Под ред. И.И.Елисеевой. -М.: Финансы и статистика, 2003. С.344.

27. Kh.S. Mukhitdinov, F.D. Juraev. Methods of Macroeconomic Modeling. International Journal of Trend in Scientific Research and Development (IJTSRD), eISSN: 2456 - 6470, 29-32 pag, 
https://www.ijtsrd.com/papers/ijtsrd38498 .pdf

28. Kh.S. Mukhitdinov, A.N.Rakhimov. "Empirical models which were built for each sector of the service sector to the population of the region". South Asian Journal Marketing \& Management Research, December 2020, Isse 12, Vol 10

29. Kh.S. Mukhitdinov, A.N.Rakhimov. The forecast for the development of the public services sector. Scopus, Solid State Technology, December 2020, Vol 63, № 6 (2020)

30. Kh.S. Mukhitdinov, G.Kh.Makhmatkulov. Providing trade services to the population of the region. International Journal of Trend in Scientific Research and Development (IJTSRD), e-ISSN: 2456 6470, 32-41 pag. https://www.ijtsrd.com/papers/ijtsrd38499 .pdf

31. Kh.S. Mukhitdinov, A.M.Rakhimov. Providing accommodation and food services to the population of the region . International Journal of Trend in Scientific Research and Development (IJTSRD), eISSN: 2456 - 6470, 42-48 pag. https://www.ijtsrd.com/papers/ijtsrd38500 .pdf 